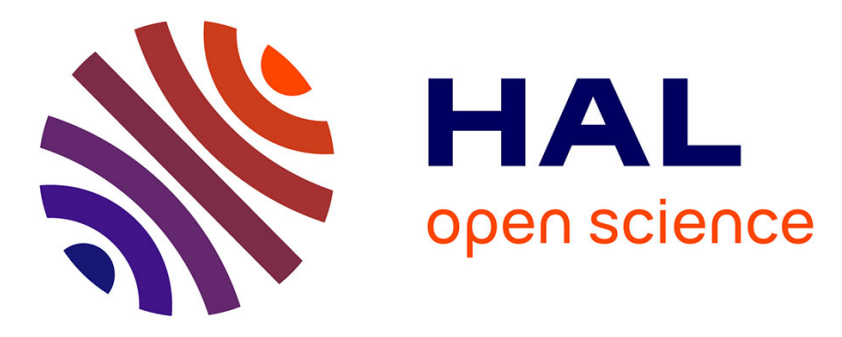

\title{
A brief guide to polymer nomenclature (IUPAC Technical Report)
}

\author{
Roger C. Hiorns, R.J. Boucher, R. Duhlev, K.-H. Hellwich, P. Hodge, A.D. \\ Jenkins, R.G. Jones, J. Kahovec, G. Moad, C.K. Ober, et al.
}

\section{- To cite this version:}

Roger C. Hiorns, R.J. Boucher, R. Duhlev, K.-H. Hellwich, P. Hodge, et al.. A brief guide to polymer nomenclature (IUPAC Technical Report). Pure and Applied Chemistry, 2012, 84 (10), pp.2167-2169. 10.1351/PAC-REP-12-03-05 . hal-01601985

\section{HAL Id: hal-01601985 https://hal.science/hal-01601985}

Submitted on 22 Mar 2021

HAL is a multi-disciplinary open access archive for the deposit and dissemination of scientific research documents, whether they are published or not. The documents may come from teaching and research institutions in France or abroad, or from public or private research centers.
L'archive ouverte pluridisciplinaire HAL, est destinée au dépôt et à la diffusion de documents scientifiques de niveau recherche, publiés ou non, émanant des établissements d'enseignement et de recherche français ou étrangers, des laboratoires publics ou privés. 


\section{A brief guide to polymer nomenclature (IUPAC Technical Report)}

R. C. Hiorns (France) $)^{\ddagger}$, R. J. Boucher (UK), R. Duhlev (UK), K.-H. Hellwich (Germany), P. Hodge (UK), A. D. Jenkins (UK), R. G. Jones (UK), J. Kahovec (Czech Republic), G. Moad (Australia), C. K. Ober (USA), D. W. Smith (USA), R. F. T. Stepto (UK), J.-P. Vairon (France), and J. Vohlídal (Czech Republic). *E-mail: polymer.nomenclature@iupac.org; Sponsoring body: IUPAC Polymer Division, Subcommittee on Polymer Terminology.

\section{1) Introduction}

The universal adoption of an agreed nomenclature has never been more important for the description of chemical structures in publishing and online searching. The International Union of Pure and Applied Chemistry (IUPAC) $^{1 \mathrm{a}, \mathrm{b}}$ and Chemical Abstracts Service $(\mathrm{CAS})^{2}$ make similar recommendations. The main points are shown here with hyperlinks to original documents. Further details can be found in the IUPAC Purple Book. ${ }^{3}$

\section{2) Basic Concepts}

The terms polymer and macromolecule do not mean the same thing. A polymer is a substance composed of macromolecules. The latter usually have a range of molar masses (unit $\mathrm{g} \mathrm{mol}^{-1}$ ), the distributions of which are indicated by dispersity $(\nexists)$. It is defined as the ratio of the mass-average molar mass $\left(M_{\mathrm{m}}\right)$ to the number-average molar mass $\left(M_{\mathrm{n}}\right)$ i.e. $(\nexists)=$ $M_{\mathrm{m}} / M_{\mathrm{n}}{ }^{4}$ Symbols for physical quantities or variables are in italic font but those representing units or labels are in roman font.

Polymer nomenclature usually applies to idealised representations; minor structural irregularities are ignored. A polymer can be named in one of two ways. Source-based nomenclature can be used when the monomer can be identified. Alternatively, more explicit structure-based nomenclature can be used when the polymer structure is proven. Where there is no confusion, some traditional names are also acceptable.

Whatever method is used, all polymer names have the prefix poly, followed by enclosing marks around the rest of the name. The marks are used in the order: $\{[()]\}$. Locants indicate the position of structural features, e.g., poly(4-chlorostyrene). If a source-based name is one word and has no locants, then the enclosing marks are not essential, but they should be used when there might be confusion, e.g., poly(chlorostyrene) is a polymer whereas polychlorostyrene might be a small, multi-substituted molecule. End-groups are described with $\alpha$ - and $\omega$-, e.g., $\alpha$-chloro- $\omega$-hydroxy-polystyrene. ${ }^{3}$

\section{3) Source-Based Nomenclature ${ }^{5}$}

\subsection{Homopolymers}

A homopolymer is named using the name of the real or assumed monomer (the 'source') from which it is derived, e.g., poly(methyl methacrylate). Monomers can be named using IUPAC recommendations, or well-established traditional names. Should ambiguity arise, class names can be added. ${ }^{6}$ For example, the source-based name poly(vinyloxirane) could correspond to either of the structures shown below. To clarify, the polymer is $\left.+\underset{\mathrm{CH}}{-\mathrm{CH}_{2}} \mathrm{~T}_{n}+\mathrm{O}-\mathrm{CH}-\mathrm{CH}_{2}\right)_{n}$ named using the polymer class $\therefore \mathrm{O} \quad \mathrm{CH}=\mathrm{CH}_{2} \quad$ name of the monomer, i.e., class left and right, respectively, are polyalkylene:vinyloxirane and polyether: vinyloxirane.

\subsection{Copolymers $^{7}$}

The structure of a copolymer can be described using the most appropriate of the connectives shown in Table 1. These are written in italic font.

\subsection{Non-linear polymers 5}

Non-linear polymers and copolymers, and polymer assemblies are named using the italicized qualifiers in Table 2. The qualifier, such as branch, is used as a prefix (P) when naming a (co)polymer, or as a connective (C), e.g., comb, between two polymer names.

To cite, please use: IUPAC. Pure Appl. Chem. 84, 2167-2169 (2012). Publication of this document by any means is permitted on condition that it is whole and unchanged. Copyright $\odot$ IUPAC 2012.
Table 1 Qualifiers for copolymers. ${ }^{7}$

\begin{tabular}{|c|c|c|}
\hline Copolymer & Qualifier & Example \\
\hline unspecified & (C) & poly(styrene-co-isoprene) \\
\hline statistical & stat & poly[isoprene-stat-(methyl methacrylate)] \\
\hline random & ran & poly [(methyl methacrylate)-ran-(butyl acrylate) $]$ \\
\hline alternating & (C) & poly[styrene-alt-(maleic anhydride)] \\
\hline periodic & per & poly[styrene-per-isoprene-per-(4-vinylpyridine)] \\
\hline block & block (C) & poly(buta-1,3-diene)-block-poly(ethene-co-propene) \\
\hline $\operatorname{graft}^{\mathrm{a}}$ & graft (C) & polystyrene-graft-poly(ethylene oxide) \\
\hline
\end{tabular}

aThe first name is that of the main chain.

Table 2 Qualifiers for non-linear (co)polymers and polymer assemblies. ${ }^{5}$

\begin{tabular}{|c|c|c|}
\hline (Co)polymer & Qualifier & Example \\
\hline blend & blend $(\mathrm{C})$ & $\begin{array}{l}\text { poly(3-hexylthiophene)-blend- } \\
\text { polystyrene }\end{array}$ \\
\hline comb & comb & polystyrene-comb-polyisoprene \\
\hline complex & compl & $\begin{array}{l}\text { poly }(2,3 \text {-dihydrothieno[3,4- } b] \\
[1,4] \text { dioxine }) \text {-compl- } \\
\text { poly(vinylbenzenesulfonic acid })^{\mathrm{a}}\end{array}$ \\
\hline cyclic & cyclo & cyclo-polystyrene-graft-polyethylene \\
\hline branch & branch & $\begin{array}{l}\text { branch-poly[(1,4-divinylbenzene)- } \\
\text { stat-styrene] }\end{array}$ \\
\hline network & net $(\mathrm{C}$ or $\mathrm{P})$ & net-poly(phenol-co-formaldehyde) \\
\hline interpenetrating network & ipn $\quad(\mathrm{C})$ & $\begin{array}{l}\text { (net-polystyrene)-ipn- } \\
{[\text { net-poly(methyl acrylate) }]}\end{array}$ \\
\hline $\begin{array}{l}\text { semi-interpenetrating } \\
\text { network }\end{array}$ & sipn & (net-polystyrene)-sipn-polyisoprene \\
\hline star & star & star-polyisoprene \\
\hline
\end{tabular}

an accordance with IUPAC organic nomenclature, square brackets enclose locants that refer to the numbering of the components of the fused ring.

\section{4) Structure-Based Nomenclature}

\subsection{Regular single-strand organic polymers ${ }^{8}$}

In place of the monomer name used in source-based nomenclature, structure-based nomenclature uses that of the preferred constitutional repeating unit (CRU). It can be determined as follows: (i) a large enough part of the polymer chain is drawn to show the structural repetition, e.g.,

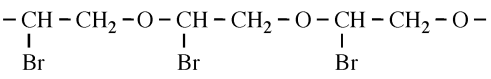

(ii) the smallest repeating portion is a CRU, so all such possibilities are identified. In this case:

$$
\begin{gathered}
-\mathrm{CH}_{2}-\mathrm{O}-\mathrm{CH}- \\
\mathrm{I} \\
\mathrm{Br} \\
-\mathrm{CH}_{2}-\mathrm{CH}-\mathrm{O}- \\
\mathrm{I} \\
\mathrm{Br}
\end{gathered}
$$

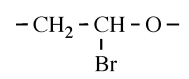$$
\begin{gathered}
-\mathrm{O}-\underset{\mathrm{I}}{\mathrm{CH}}-\mathrm{CH}_{2}- \\
\mathrm{Br}
\end{gathered}
$$$$
\begin{aligned}
& -\mathrm{CH}-\mathrm{CH}_{2}-\mathrm{O}- \\
& \mathrm{I} \\
& \mathrm{Br} \\
& -\mathrm{O}-\mathrm{CH}_{2}-\mathrm{CH}- \\
& \mathrm{I} \\
& \mathrm{Br}
\end{aligned}
$$

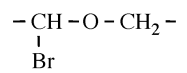

(iii) the next step is to identify the subunits that make up each of these structures, i.e., the largest divalent groups that can be named using IUPAC nomenclature of organic compounds such as the examples that are listed in Table 3; (iv) using the shortest path from the most senior subunit to the next senior, the correct order of the subunits is determined using Fig. 1; (v) the preferred CRU is chosen as that with the lowest possible locant(s) for substituents.

\footnotetext{
${ }^{1}$ Freely available on: (a) http://www.iupac.org/publications/pac/; (b) http://www.chem.qmul.ac.uk/iupac/ ${ }^{2}$ http://www.cas.org/

${ }^{3}$ IUPAC. The "Purple Book", RSC Publishing, Cambridge, UK (2008).

4IUPAC. Pure Appl. Chem. 81, 351 (2009).

${ }^{5}$ IUPAC. Pure Appl. Chem. 69, 2511 (1997).

${ }^{6}$ IUPAC. Pure Appl. Chem. 73, 1511 (2001).

${ }^{7}$ IUPAC. Pure Appl. Chem. 57, 1427 (1985).

${ }^{8}$ IUPAC. Pure Appl. Chem. 74, 1921 (2002).
} 
In the above example, the oxy subunits in the CRUs are heteroatom chains. From Fig. 1, oxy subunits are senior to the acyclic carbon chain subunits, the largest of which are bromo-substituted $-\mathrm{CH}_{2}-\mathrm{CH}_{2}$ - subunits. 1-Bromoethane-1,2-diyl is chosen in preference to 2-bromoethane-1,2-diyl as the former has a lower locant for the bromo-substituent. The preferred CRU is therefore oxy(1-bromoethane-1,2-diyl) and the polymer is thus named poly[oxy(1-bromoethane-1,2-diyl)]. Please note the enclosing marks around the subunit carrying the substituent.

Polymers that are not made up of regular repetitions of a single CRU are called irregular polymers. For these, each constitutional unit (CU) is separated by a slash, e.g., poly(but-1-ene-1,4-diyl/1-vinylethane-1,2-diyl). ${ }^{9}$

Table 3 Representations of divalent groups in polymers. ${ }^{8}$

\begin{tabular}{|c|c|c|c|}
\hline Name & Group $^{a}$ & Name & Group $^{a}$ \\
\hline oxy & $-\mathrm{O}-$ & propylimino & $\begin{array}{l}-\mathrm{N}- \\
\stackrel{\mathrm{I}}{\mathrm{CH}_{2}} \mathrm{CH}_{2} \mathrm{CH}_{3}\end{array}$ \\
\hline sulfanediyl & $-S-$ & hydrazine-1,2-diyl & $\stackrel{1}{\mathrm{~N}} \mathrm{H}-\stackrel{2}{\mathrm{~N}} \mathrm{H}-$ \\
\hline sulfonyl & $-\mathrm{SO}_{2}-$ & phthaloyl & \\
\hline diazenediyl & $-\mathrm{N}=\mathrm{N}-$ & 1,4-phenylene & \\
\hline imino & $-\mathrm{NH}-$ & cyclohexane-1,2-diyl & \\
\hline carbonyl & $\begin{array}{c}\mathrm{O} \\
\stackrel{1}{1} \\
-\mathrm{C}-\end{array}$ & butane-1,4-diyl & $-\stackrel{1}{\mathrm{C}} \mathrm{H}_{2} \stackrel{2}{\mathrm{C}} \mathrm{H}_{2} \stackrel{3}{\mathrm{C}_{2}} \stackrel{4}{\mathrm{C}}_{2}$ \\
\hline oxalyl & 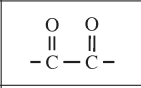 & 1-bromoethane-1,2-diyl & $\begin{array}{l}\stackrel{1}{\mathrm{C}} \mathrm{H}-\stackrel{2}{\mathrm{C}} \mathrm{H}_{2}- \\
\stackrel{\mathrm{Br}}{\mathrm{B}}- \\
\end{array}$ \\
\hline silanediyl & $-\mathrm{SiH}_{2}-$ & 1-oxopropane-1,3-diyl & $\stackrel{\mathrm{O}}{\mathrm{II}} \underset{\mathrm{C}}{\mathrm{C}}-\stackrel{2}{\mathrm{C}} \mathrm{H}_{2} \stackrel{3}{\mathrm{C}} \mathrm{H}_{2}-$ \\
\hline ethane-1,2-diyl & $-\stackrel{1}{\mathrm{C}} \mathrm{H}_{2}-\stackrel{2}{\mathrm{C}} \mathrm{H}_{2}-$ & ethene-1,2-diyl & $-\stackrel{1}{\mathrm{C}} \mathrm{H}=\stackrel{2}{\mathrm{C}} \mathrm{H}-$ \\
\hline methylene & $-\mathrm{CH}_{2}-$ & methylmethylene & $\begin{array}{c}-\mathrm{CH}- \\
\mathrm{I}- \\
\mathrm{CH}_{3}\end{array}$ \\
\hline
\end{tabular}

aTo avoid ambiguity, wavy lines drawn perpendicular to the free bond, which are conventionally used to indicate free valences, ${ }^{13}$ are usually omitted from graphical

representations in a polymer context.

\subsection{Regular double-strand organic polymers ${ }^{10}$}

Double-strand polymers consist of uninterrupted chains of rings. In a spiro polymer, each ring has one atom in common with adjacent rings. In a ladder polymer, adjacent rings have two or more atoms in common. To identify the preferred CRU, the chain is broken so that the senior ring is retained with the maximum number of heteroatoms and the minimum number of free valences.

An example is 10 . The preferred CRU is an acyclic subunit of 4 carbon atoms with 4 free valences, one at each atom, as shown below. It is oriented so that the lower left atom has the lowest number. The free-valence locants are written before the suffix, and they are cited clockwise from the 4 lower left position as: lower-left, upper-left:upper-right, lowerright. This example is thus named poly(butane-1,4:3,2-tetrayl).

1 For more complex structures, the order of seniority again follows Fig. 1.

5) Nomenclature of Inorganic and Inorganic-Organic Polymers ${ }^{11}$

Some regular single-strand inorganic polymers can be named like organic polymers using the rules given above, e.g., $\left\lceil\mathrm{O}-\mathrm{Si}\left(\mathrm{CH}_{3}\right)_{2} \ddagger_{n}\right.$ and $\mathfrak{\uparrow n}\left(\mathrm{CH}_{3}\right)_{2} \ddagger_{n}$ are named poly[oxy(dimethylsilanediyl)] and poly(dimethylstannanediyl), respectively. Inorganic polymers can also be named in accordance with

${ }^{9}$ IUPAC. Pure Appl. Chem. 66, 873 (1994)

${ }^{10}$ IUPAC. Pure Appl. Chem. 65, 1561 (1993).

${ }^{11}$ IUPAC. Pure Appl. Chem. 57, 149 (1985).

${ }^{12}$ IUPAC. Pure Appl. Chem. 66, 2469 (1994).

${ }^{13}$ IUPAC. Pure Appl. Chem. 80, 277 (2008).

${ }^{14}$ Macromolecules 1, 193 (1968).

${ }^{15}$ Polym. Prepr. 41(1), 6a (2000). inorganic nomenclature, but it should be noted that the seniority of the ele-

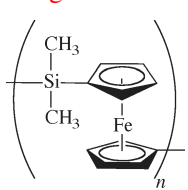
ments is different to that in organic nomenclature. However, certain inorganic-organic polymers, for example those containing metallocene derivatives, are at present best named using organic nomenclature, e.g., the polymer on the left can be named poly[(dimethylsilanediyl)ferrocene-1,1'-diyl].

\section{6) Traditional Names}

When they fit into the general pattern of systematic nomenclature, some traditional and trivial names for polymers in common usage, such as polyethylene, polypropylene, and polystyrene, are retained.

\section{7) Graphical Representations ${ }^{12,13}$}

The bonds between atoms can be omitted, but dashes should be drawn for chain-ends. The seniority of the subunits does not need to be followed. For single-strand (co)polymers, a dash is drawn through the enclosing marks, e.g., poly[oxy(ethane-1,2-diyl)] shown below left. For irregular polymers, the CUs are separated by slashes, and the dashes are drawn inside the enclosing marks. End-groups are connected using additional dashes outside of the enclosing marks, e.g., $\alpha$-methyl- $\omega$-hydroxy-poly[oxirane-co(methyloxirane)], shown below right.

$$
-\left(\mathrm{OCH}_{2} \mathrm{CH}_{2}\right)_{n} \quad \mathrm{CH}_{3}-\left(-\mathrm{OCH}_{2} \mathrm{CH}_{2}-/-\underset{\mathrm{CH}_{3}}{\mathrm{OCHCH}_{2}}-\right)_{n}-\mathrm{OH}
$$

\section{8) CA Index Names ${ }^{2}$}

CAS maintains a registry of substances. In the CAS system, the CRU is called a structural repeating unit (SRU). There are minor differences in the placements of locants, e.g., poly(pyridine-3,5-diylthiophene-2,5-diyl) is poly(3,5-pyridinediyl-2,5-thiophenediyl) in the CAS registry, but otherwise polymers are named using similar methods to those of IUPAC. ${ }^{14,15}$

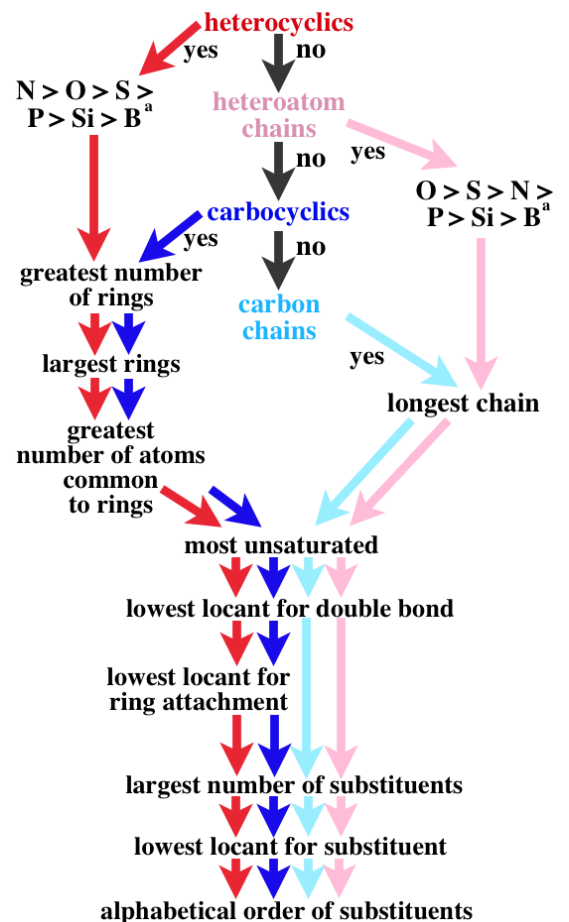

Fig. 1 The order of subunit seniority. The senior subunit is at the top centre. Subunits of lower seniority are found by following the arrows. The type of subunit, be it a heterocycle, a heteroatom chain, a carbocycle, or a carbon chain, determines the colour of the arrow to follow. ${ }^{a}$ Other heteroatoms may be placed in these orders as indicated by their positions in the periodic table. ${ }^{8}$

Pure Appl. Chem., Vol. 84, No. 10, pp. 2167-2169, 2012 


\section{MEMBERSHIP OF SPONSORING BODIES}

Membership of the IUPAC Polymer Division Committee for the period 2012-2013 is as follows: President: M. Buback (Germany); Vice President: G. T. Russell (New Zealand); Secretary: M. Hess (Germany); Past President: C. K. Ober (USA); Titular Members: D. Dijkstra (Germany); R. C. Hiorns (France); P. Kubisa (Poland); G. Moad (Australia); W. Mormann (Germany); D. W. Smith (USA); Associate Members: J. He (China); R. G. Jones (UK); I. Lacík (Slovakia); M. Sawamoto (Japan); Y. Yagci (Turkey); M. Žigon (Slovenia); National Representatives: V. P. Hoven (Thailand); M. A. Khan (Bangladesh); J.-S. Kim (Korea); M. Malinconico (Italy); N. Manolova (Bulgaria); S. Margel (Israel); G. S. Mhinzi (Tanzania); A. M. Muzafarov (Russia); M. I. Sarwar (Pakistan); J. Vohlídal (Czech Republic).

Membership of the Subcommittee on Polymer Terminology for the period 2009-2012 is as follows: Chair: R. G. Jones (UK); Secretary: T. Kitayama (Japan), 2008-2009; R. C. Hiorns (France), from 2010; Members: G. Allegra (Italy); M. Barón (Argentina); T. Chang (Korea); A. Fradet (France); J. He (China); K.-H. Hellwich (Germany); M. Hess (Germany); P. Hodge (UK); K. Horie ${ }^{\dagger}$ (Japan); A. D. Jenkins (UK); J.-I. Jin (Korea); J. Kahovec (Czech Republic); P. Kratochvíl (Czech Republic); P. Kubisa (Poland); C. K. Luscombe (USA); S. V. Meille (Italy); I. Mita (Japan); G. Moad (Australia); W. Mormann (Germany); T. Nakano (Japan); C. K. Ober (USA); S. Penczek (Poland); G. T. Russell (New Zealand); C. dos Santos (Brazil); F. Schué (France); S. Słomkowski (Poland); D. W. Smith (USA); R. F. T. Stepto (UK); N. Stingelin (UK); D. Tabak (Brazil); J.-P. Vairon (France); M. Vert (France); J. Vohlídal (Czech Republic); M. G. Walter (USA); E. S. Wilks (USA).

Republication or reproduction of this report or its storage and/or dissemination by electronic means is permitted without the need for formal IUPAC permission on condition that an acknowledgment, with full reference to the source, along with use of the copyright symbol $\odot$, the name IUPAC, and the year of publication, are prominently visible. Publication of a translation into another language is subject to the additional condition of prior approval from the relevant IUPAC National Adhering Organization.

$\dagger$ Deceased. 